\title{
Caddo Sites in the Saline Creek Basin in Northern Smith County, Texas
}

Timothy K. Perttula

Heritage Research Center, Stephen F. Austin State University

Mark Walters

Heritage Research Center, Stephen F. Austin State University

Follow this and additional works at: https://scholarworks.sfasu.edu/ita

Part of the American Material Culture Commons, Archaeological Anthropology Commons, Environmental Studies Commons, Other American Studies Commons, Other Arts and Humanities Commons, Other History of Art, Architecture, and Archaeology Commons, and the United States History Commons

Tell us how this article helped you.

This Article is brought to you for free and open access by the Center for Regional Heritage Research at SFA ScholarWorks. It has been accepted for inclusion in Index of Texas Archaeology: Open Access Gray Literature from the Lone Star State by an authorized editor of SFA ScholarWorks. For more information, please contact cdsscholarworks@sfasu.edu. 


\section{Caddo Sites in the Saline Creek Basin in Northern Smith County, Texas \\ Creative Commons License \\ (c) (1) \& 8}

This work is licensed under a Creative Commons Attribution-NonCommercial 4.0 International License 


\title{
Caddo Sites in the Saline Creek Basin in Northern Smith County, Texas
}

\author{
Timothy K. Perttula and Mark Walters
}

\section{INTRODUCTION}

This article concerns the documentation of the artifacts from four prehistoric Caddo sites in the Saline Creek drainage basin in the Post Oak Savannah in northern Smith County, Texas (Diggs et al. 2006:Figures 1-3). Saline Creek is a northward-flowing tributary to the Sabine River. The Caddo sitcs arc ca. $10 \mathrm{~km}$ south of the confluence of Saline Creek with the Sabine River. Saline Creek enters into the Sabine River about 6 $\mathrm{km}$ east (downstream) of the confluence of a major tributary, Lake Fork Creek, with the river.

\section{THE SITES AND COLLECTIONS}

The four sites discussed in this article were recently recorded by Mark Walters, a Texas Archeological Stewards Network steward for East Texas, at the behest of the private landowner. During periodic land clean-up and clearing, the landowner discovered and collected visible surface artifacts at each of the sites, keeping them separate until they could be properly studied and put on record. The documentation effort took place in May 2011. A fifth site-the Bateman cache (41SM443)-is under study by Dr. Harry J. Shafer.

\section{Sarah's Deer Stand (41SM440)}

The Sarah's Deer Stand site is located on a sandy (Gallime fine sandy loam, 1-5\% slopes. Hatherly 1993) upland ridge that slopes to the west towards Saline Creek, the current channel of which is $540 \mathrm{~m}$ to the west. When the site was recorded in 2010 , it had small hardwoods, brush, and a weedy understory; surface visibility was $5 \%$. It has been estinated to cover a $2500 \mathrm{~m}^{2}$ area $(0.62 \mathrm{acres})$. There is one area of the site that has crepe myrtle bushes and a charcoal-stained area; these probably are associated with a 19 th century component (see below).

There are 155 Caddo sherds in the collections from the Sarah's Deer Stand site, 42 (27\%) of which have decorations. The plain to decorated sherd ratio is 2.69 . The assemblage is from sherds that are primarily tempered only with grog $(85 \%)$, although some shcrds also have bone $(12.9 \%)$ and hematite (2\%) inclusions. Detailed analysis of a $9 \%$ sample of the sherds (Table 1) indicate that $21 \%$ of the sherds are from vessels fired in a high oxygen or oxidizing environment, and another $35.7 \%$ are from vessels incompletely oxidized during firing. The remainder of the sherds ( $42.9 \%)$ are from vessels fired in a low oxygen or reducing environment; half of these sherds are from vessels that were also cooled in a reducing environment, and the other half were from vessels that were cooled in the open air, leaving a thin oxidized surfacc and core on either one or both vessel surfaces.

The sherds from the site are well-preserved, as is indicated by the fact that $57 \%$ of them have evidence of surface trcatment (smoothing) on either one or both vessel surfaces (see Table 1). Vessels werc medium to large in size, based on the mean body wall thickncss of $8.05 \pm 0.95 \mathrm{~mm}$ (range 6.2-10.7 $\mathrm{mm}$ ), many of them probably used for cooking and storage.

Journal of Northeast Texas Archaeology, Volume 36, 2012 
Table 1. Detailed analysis of Caddo sherds from Sarah's Deer Stand site.

\begin{tabular}{|c|c|c|c|c|c|}
\hline Sherd type & Temper & $\mathrm{FC}$ & ST & $\begin{array}{l}\text { Th } \\
(\mathrm{mm})\end{array}$ & Comments \\
\hline body & grog & G & E SM & 7.0 & $\begin{array}{l}\text { engraved circles and hatched triangle areas; } \\
\text { cf. Poynor Engraved }\end{array}$ \\
\hline body & grog & G & - & 8.3 & plain \\
\hline body & grog & B & E SM & 6.2 & plain \\
\hline body & grog & $B$ & $\begin{array}{l}1 / \mathrm{E} \\
\mathrm{SM}\end{array}$ & 7.1 & plain \\
\hline body & grog & A & $\begin{array}{l}\mathrm{I} / \mathrm{E} \\
\mathrm{SM}\end{array}$ & 8.6 & plain \\
\hline body & grog & $\mathrm{B}$ & - & 9.0 & plain \\
\hline body & grog-bone & $\mathrm{E}$ & I SM & 10.7 & parallel brushed \\
\hline body & grog-bone & A & - & 10.1 & plain \\
\hline body & grog-hem. & $\mathrm{C}$ & - & 7.1 & parallel brushed \\
\hline body & grog-hem. & A & & 7.6 & parallel incised lines \\
\hline body & grog-hem. & $\mathrm{C}$ & $\begin{array}{l}\mathrm{I} / \mathrm{E} \\
\mathrm{SM}\end{array}$ & 6.6 & curvilinear engraved lines \\
\hline body & $\begin{array}{l}\text { grog-bone- } \\
\text { hem. }\end{array}$ & G & - & 8.4 & $\begin{array}{l}\text { parallel brushed with tool punctates pushed } \\
\text { through the brushing }\end{array}$ \\
\hline body & $\begin{array}{l}\text { grog-bone- } \\
\text { hem. }\end{array}$ & $E$ & I SM & 8.9 & plain \\
\hline body & $\begin{array}{l}\text { grog-sandy } \\
\text { paste }\end{array}$ & $\mathrm{E}$ & I SM & 7.1 & plain \\
\hline
\end{tabular}

hem.=hematite: $\mathrm{FC}=$ firing conditions: $\mathrm{A}=$ fired and cooled in an oxidizing environment: $\mathrm{C}-\mathrm{E}$, incompletely oxidized during firing; $\mathrm{B}=$ fired and cooled in a reducing environment; $\mathrm{F}-\mathrm{G}=$ fired in a reducing environment and cooled in the open air; STsurface treatment: I=interior; E=exterior: $\mathrm{SM}=$ smoothed; Th=thickness

The 42 decorated sherds are predominanlly from utility ware vessels $(92.9 \%)$, with only three fine ware sherds $(7.1 \%$ of the decorated sherds). Almost $43 \%$ of the decorated sherds and $46 \%$ of the utility wares have brushed body decorations, either parallel or vertical $(n=16)$ or overlapping $(n=2)$ brushed marks. Two parallel brushed body sherds, possibly from Bullard Brushed jars (see Suhm and Jelks 1962:Plate 11), have tool punctations pushed through the brushing marks.

Fourteen (33\% of the decorated sherds have incised lines as the decorative method, with either parallel or straight $(n=12)$ and opposed line $(n=2)$ elements. Four sherds ( $9.5 \%$ of the decorated sherds), including a rim, have rows of tool punctations either on the rim and/or the body of jars. The remaining utility ware sherd has pinched rows; this may be from a Killough Pinched jar (Suhm and Jelks 1962:Plate 46).

Two of the fine ware body sherds have curvilinear engraved lines, while the third, from a bottle, has an engraved circle within a circle surrounded by a curvilinear arc of fine engraved lines (Figure 1a). The use of a curvilinear are of cngraved lines on this sherd is similar to other examples of Poynor Engraved, possibly including Poynor Engraved, var. Lang (Perttula 2011:Figure 6-64f-g), although this style is most commonly seen on carinated bowls rather than bottles. 


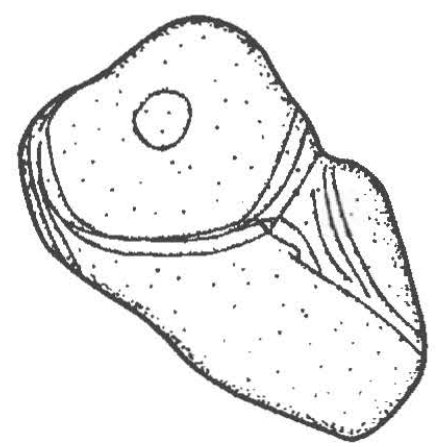

a

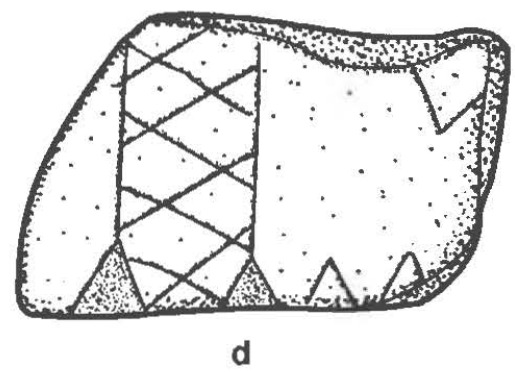

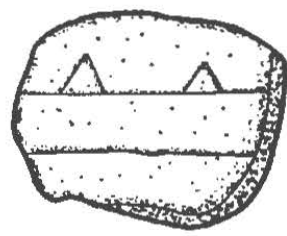

b

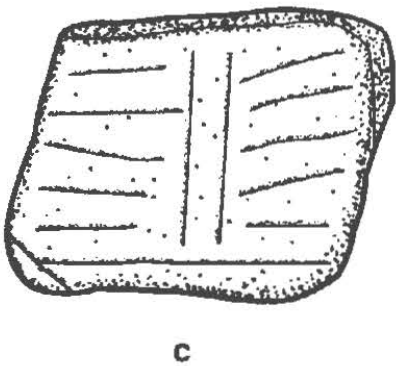

0

10 20

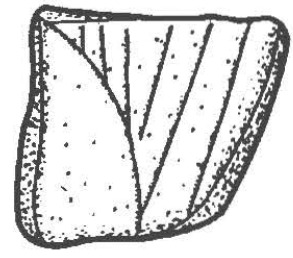

e

Figurc 1. Selected decorated sherds from the Saline Creek sites: a, cf. Poynor Engraved, 41SM440: b, parallel engraved and pendant triangles, 4141SM442; c, horizontal-vertical engraved and opposed engraved lines, 41SM442; d, crosshatched engraved column and cxcised and plain pendant triangles, 41SM442; e, cf. Poynor Engraved, var. Hood, 4ISM444. Drawings by Lance Trask.

The chipped stone artifacts from the Sarah's Deer Stand site include 13 tools or tool fragments, 84 picces of lithic debris, and four cores (Table 2). The lithic artifacts indicate that the site was first used by aboriginal peoples during the Late Archaic (ca. 5000-2500 years ago), as marked by the Yarbrough dart points and the ferruginous sandstone gouge. The mcan stem width of the five Gary points from the site $(13.02 \mathrm{~mm})$ suggests these are Gary, var. Camden points from a more intensive occupation during the latter part of the Wondland period (ca. A.D. 200-700). The arrow point preform may be associated with the prehistoric Caddo component recognized in the ceramic sherds, but its presence does mean that arrow points were made on site during some period of Caddo use.

The lithic debris from the sitc is primarily from locally available raw materials, especially a quartzite that had to be heat-treated before it could be successfully reduced (see Table 2). Nevertheless, non-local lithic debris (probably from Red River gravels or source areas in the Ouachita Mountains) accounts for $27 \%$ of the lithic debris sample; $25 \%$ of the cores are on non-local raw material; and $7.7 \%$ of the chipped stone tools are on non-local lithic raw materials.

In addition to the chipped stone artifacts, there are four ground stone tools in the site collection. These are a ferruginous sandstone metate and mano, used in the past for grinding maize and seeds, a bi-pitted stone of ferruginous sandstone, as well as a fragment of a polished igneous rock, probably a celt fragment. Three quartzite fire-cracked rocks suggest that a modicum of hot rock cooking of plant foods (especially roots) took place at the site during one of the occupations. 
Table 2. Lithic Artifacts from Sarah's Deer Stand Site.

\begin{tabular}{|c|c|c|}
\hline Category & Number & Percentage \\
\hline Arrow point preform, quartzite & 1 & 1.0 \\
\hline Gary dart point, quartzite & 3 & 3.0 \\
\hline Gary dart point, quartzite & 1 & 1.0 \\
\hline Gary dart point, dark gray chert & 1 & 1.0 \\
\hline Yarbrough dart point, quartzite & 2 & 2.0 \\
\hline Dart point tip, quartzitc & 1 & 1.0 \\
\hline Bifacial tool fragment, quartzite & 1 & 1.0 \\
\hline Biface preform, yuartzite & 2 & 2.0 \\
\hline Gouge, ferruginuus sandstone & 1 & 1.0 \\
\hline Subtotal & 13 & 12.9 \\
\hline Lithic debris, subtutal & 84 & 83.2 \\
\hline quartzite & 51 & 50.5 \\
\hline petrified wood & 3 & 3.0 \\
\hline chalcedony & 6 & 5.9 \\
\hline ferruginous sandstone & 1 & 1.0 \\
\hline non-local chert & 23 & 22.8 \\
\hline Core, subtotal & 4 & 4.0 \\
\hline single platform, quartzitc & 1 & 1.0 \\
\hline $\begin{array}{l}\text { multiple platform, } \\
\text { petrified wood }\end{array}$ & 1 & 1.0 \\
\hline multiple platform, red chert & 1 & 1.0 \\
\hline $\begin{array}{l}\text { core fragment, dark grayish- } \\
\text { brown chert }\end{array}$ & 1 & 1.0 \\
\hline Totals & 101 & 100.0 \\
\hline
\end{tabular}

There is also a pre-Civil War component at the site, although its extent and character are unknown. This occupation is marked by a chert blade gunflint (for a rifle or musket) and several transfer-printed whiteware sherds. The latter were made from ca. 1830s-1860 (Samford 2000).

\section{Handicap Deer Stand (41SM441)}

This site is in a similar setting as the Sarah's Deer Stand site, as it is located on a sandy upland ridge that slopes towards Saline Creek, about $500 \mathrm{~m}$ to the west. The landform has Cuthbert fine sandy loam soils. The site itself had a few hardwood trees, brush, and weeds, and a ground surface visibility of $5 \%$. The Handicap Deer Stand site is estimated to cover $2400 \mathrm{~m}^{2}(0.6$ acres $)$ in size. 
A total of 47 sherds comprise the collection of Caddo ceramic wares from the Handicap Deer Stand site, 32 plain rim, body and base sherds and 15 decorated rim and body sherds. The sherds are from vessels that are primarily grog-tempered, but $17 \%$ also have bone temper. At least one sherd is from a vessel made with a naturally sandy paste, based on the detailed analysis of a small sample of sherds from the site (Tablc 3). Firing vessels in a reducing environment was the preferred manner employed by the Caddo potters at the site. A majority of the vessels were smonthed on one or both surfaces as part of finishing the vessels and making them ready for use for food serving, cooking, and storage. Rim and body wall thickness of the sherds analyzed in detail indicate that the vessels were built to be durable, with thick rims $(9.3 \mathrm{~mm})$ and moderately thick body walls $(6.97 \pm 1.48 \mathrm{~mm}$, range $=5.1-8.6 \mathrm{~mm})$.

Table 3. Detailed analysis of Caddo sherds from the Handicap Deer Stand site.

\begin{tabular}{llllll}
\hline Sherd type & Temper & FC & ST & $\begin{array}{l}\text { Th } \\
(\mathrm{mm})\end{array}$ & Comments \\
\hline body & grog & H & - & 8.0 & fingernail punctated row \\
body & grog & F & I SM & 7.6 & parallel brushed \\
body & grog & B & I/E & 5.4 & plain; ext. organic residue \\
body & grog & B & I SM & 5.1 & plain \\
rim & grog-bone & F & E SM & 9.3 & plain \\
body & grog-bone & B & I SM & 7.1 & plain \\
body & $\begin{array}{l}\text { grog-sandy } \\
\text { paste }\end{array}$ & F & - & 8.6 & plain \\
\hline
\end{tabular}

$\mathrm{FC}=$ firing conditions; $\mathrm{A}=$ fired and cooled in an oxidizing environment; $\mathrm{C}-\mathrm{E}$, incompletely oxidized during firing; $\mathrm{B}=$ fired and cooled in a reducing environment: $\mathrm{F}$ - $\mathrm{G}$-fired in a reducing environment and cooled in the open air: ST-surface treatment: $I=$ interior; $E=$ exterior; $S M=$ smoothed; Th=thickness

The small sample of decorated sherds from the Handicap Deer Stand site include both utility wares $(\mathrm{n}=13,87 \%)$ and fine wares $(\mathrm{n}=2,13 \%)$. The utility wares include parallel brushed body sherds $(\mathrm{n}=7$, $47 \%$ of the decorated sherds), three sherds $(20 \%)$ with parallel incised lines, a rim sherd with horizontal incised lines, and two body sherds with rows of fingcrnail punctations.

Both fine ware sherds are from red-slipped vessels. The use of slipping as a dccorative method first hecome prominent on East Texas Caddo sites between ca. A.D. 1200-1450, in the Middle Caddo period, especially in the upper Neches, upper Sabine, and parts of the middle reaches of the Red River basin.

The chipped stone tools from the site consist of one Woodland period Gary dart point and four arrow points. The Gary, var. Camden point fragment (see Schambach 1982), made from quartzite, has the narrow stem width $(13.0 \mathrm{~mm})$ of this defined variety. This particular variety of Gary point was manufactured between ca. A.D. 200-700, during the latter part of the Woodland period. Three of the points are parallelstemmed Alba points, both unilacially and bifacially worked. The unifacial Alba points are made from non-local gray chert, while the bifacially worked specimen is on a local quartzitc. The fourth point is a contracting stem unifacial Perdiz, made on a gray chert. The two different arrow points suggest that the sitc was used by the Caddo on two different occasions, since they are not thought to be contemporaneous (see Tumer and Hester 1999): the Alba points were apparently made and used between ca. A. D. 8001200/1300, based on the dating of the Alto phase component at the George C. Davis site (Story 2000), 
while the Perdiz point may have first been manufactured ca. A.D. 1200, but continued to be made and used well into the early 18th century in East Texas (cf. Story 1995).

There is a large ( $77 \times 51 \mathrm{~mm}$ in length and width, and $37 \mathrm{~mm}$ thick) cohble-sized core with five flake removals; it is of a local tan chert, with a grayish-brown cortex. A second core has a single platform of flake removals; it is on a reddish-gray chert that is probably not from a local lithic raw material sourcc. There are 28 pieces of lithic debris in the collection. including flakes from a local quartzite $(68 \%)$ and several kinds of non-local chert (32\%). namely gray, dark gray, and yellowish-gray brown chert. The likely source of these raw materials is the Rcd River gravels and the Ouachita Mountains of southeastern Oklahoma.

The one ground stone tool from the Handicap Deer Stand sitc is a quartzite mano. It has smoothing on one side from its use in grinding actions on a metate or grinding slab, and there is a slight circular depression on one face, suggesting it may also have becn used as a pitted stone.

\section{Alligator Pond (41SM442)}

The Alligator Pond site is situated on two sandy upland ridge slopes that extend west to Saline Creek. Currently the area is part of a 4 year old pine plantation, some portions of which have been cleared for brush control; the small pine trees, brush, and weeds limit the surface visibility to $10 \%$, except in the cleared areas. Sediments on the landform are Attoyac line sandy loam. The site's extent is estimated at $6000 \mathrm{~m}^{2}$ (1.5 acres).

The principal artifact in the Alligator Pond site collection is sherds from plain ware, utility ware, and fine ware ceramic vesscls: 503 sherds in all. The sherds include three plain rims, 405 plain body sherds, and 23 base sherds, as well as 72 decorated sherds; these consist of four rim sherds (all from utility ware vessels) and 68 body sherds. The plain to decorated sherd ratio is a high 5.99 .

The sherds are from prehistoric Caddo vessels that arc principally tempered with grog $(92.2 \%)$ (Table 4). Approximately $7 \%$ of the sherds are bone-tempered, along with $0.8 \%$ that have crushed hematite pieces that were employed as temper inclusions. Two plain body sherds are not tempered and have a naturally sandy paste; they are likely Woodland period sherds belonging to the type-variety Goose Creek Plain, var. unspecified (Aten and Bollich 2011); this kind of reduced fired sandy paste pottery was made between ca. 500 B.C. and A.D. 700 .

Table 4. Detailed analysis of Caddo sherds from the Alligator Pond site.

\begin{tabular}{llllll}
\hline Sherd type & Temper & FC & ST & $\begin{array}{l}\text { Th } \\
(\mathrm{mm})\end{array}$ & Comments \\
\hline body & grog & G & - & 7.3 & plain \\
body & grog & G & - & 6.4 & plain; int. organic residue \\
body & grog & E & - & 8.6 & plain \\
body & grog & B & - & 7.3 & plain \\
body & grog & D & - & 9.5 & plain \\
body & grog & B & - & 6.5 & plain \\
body & grog & G & - & 5.4 & plain; int. organic residue \\
body & grog & F & I SM & 8.0 & plain \\
body & grog & C & - & 8.4 & plain \\
body & grog & F & I/E & 6.0 & int./ext. red-slipped \\
& & & SM & &
\end{tabular}


Table 4. Detailed analysis of Caddo sherds from the Alligator Pond site, cont.

\begin{tabular}{|c|c|c|c|c|c|}
\hline Sherd type & Temper & $\mathrm{FC}$ & ST & $\begin{array}{l}\text { Th } \\
(\mathrm{mm})\end{array}$ & Comments \\
\hline body & grog & A & I SM & 6.9 & $\begin{array}{l}\text { parallel brushed and overlying } \\
\text { opposed incised lines }\end{array}$ \\
\hline body & grog & $\mathrm{G}$ & - & 8.3 & $\begin{array}{l}\text { parallel incised lines adjacent to a } \\
\text { fingernail punctated zone }\end{array}$ \\
\hline body & grog & $\mathrm{C}$ & I SM & 7.1 & tool punctated rows \\
\hline body & grog & B & - & 7.4 & fingernail punctated rows \\
\hline body & grog & F & - & 8.7 & parallel inciscd lines \\
\hline body & grog & B & - & 9.4 & cross-hatched incised \\
\hline body & grog-bone & A & E SM & 7.1 & plain \\
\hline body & grog-bone & $\mathrm{C}$ & - & 6.0 & plain \\
\hline body & grog-hem. & A & - & 8.9 & plain \\
\hline body & grog-hem. & $\mathrm{F}$ & - & 9.6 & plain \\
\hline body & $\begin{array}{l}\text { grog-hem.- } \\
\text { sandy paste }\end{array}$ & G & - & 7.4 & plain \\
\hline body & grog-organics & $\mathrm{F}$ & - & 7.7 & plain \\
\hline body & $\begin{array}{l}\text { grog-sandy } \\
\text { paste }\end{array}$ & $\mathrm{G}$ & I SM & 5.7 & plain \\
\hline body & grog-sandy & $\mathrm{E}$ & - & 6.7 & parallel incised lines paste \\
\hline body & sandy paste & B & I SM & 7.1 & Woodland period sherd, plain \\
\hline
\end{tabular}

hem.=hematite; $\mathrm{FC}$ =firing conditions: $\mathrm{A}=$ fired and cooled in an oxidizing environnent; $\mathrm{D}-\mathrm{E}$, incompletely oxidized during firing; $\mathrm{B}=$ tired and cooled in a reducing environment: $\mathrm{F}-\mathrm{G}=$ fired in a reducing environment and cooled in the open air; STsurface treatment: I=interior; E=exterior; $S M=$ smoothed; Th=thickncss

Based on the detailed analysis of a small sample of sherds from the Alligator Pond site, the sherds are from vessels that were fired in several different ways. Foremost, some $64 \%$ of the sherds are from vessels fired in a low oxygen or reducing environment, $24 \%$ were incompletely oxidized during firing, and $12 \%$ were fired in a high oxygen environment (see Table 4). Only a few sherds have been smoothed on either interior and/or exterior surfaces. The vessels at the site wcrc coil-made, starting from a flat disk base, and they have relatively thick body walls: a mean thickness of 7.44 $\pm 0.96 \mathrm{~mm}$, with a range of 5.4-9.6 mm. Vessels of different sizes and volume were obviously in use at the Alligator Pond site during its Caddo occupation.

Of the 72 decorated sherds, $75 \%$ are from utility ware vessels (Table 5). The utility wares are dominated by sherds from vessels with incised decorations ( $38.9 \%$ of all the decorated sherds); the incised designs are almost exclusively from straight line/horizontal and vertical to simple geometric designs, including curvilinear, cross-hatched, and opposed elements. Vessels with tool and fingernail punctations --including rows of punctations-comprise $22.2 \%$ of the decorated sherds from the site. Other decorative methods represented in the Alligator Pond utility ware sherds are brushed (9.7\%), incisedpunctated $(2.8 \%)$, and appliqued (1.4\%) (Table 5 ). The low percentage of brushed sherds suggests that the Caddo occupation here took place before the other Saline Creek Caddo sites (see below), perhaps several hundred years earlier. 
Table 5. Decorated Sherds in the Alligator Pond ceramic assemblage.

\begin{tabular}{|c|c|c|}
\hline Ware and Decoration & Number & Percentage \\
\hline \multicolumn{3}{|l|}{ Utility Ware } \\
\hline appliqued node, body & 1 & 1.4 \\
\hline brushed, parallel, body & 5 & 6.9 \\
\hline brushed, parallel and overlying & 1 & 1.4 \\
\hline \multicolumn{3}{|l|}{ opposed incised lines, body } \\
\hline brushcd, overlapping and finger-nail & 1 & 1.4 \\
\hline \multicolumn{3}{|l|}{ punctates through brushing, body } \\
\hline incised, straight line, body & 6 & 8.3 \\
\hline incised, cross-hatched, rim & 1 & 1.4 \\
\hline incised, cross-hatched, body & 4 & 5.6 \\
\hline incised, curvilinear, body & 1 & 1.4 \\
\hline incised, parallel, body & 9 & 12.5 \\
\hline incised-parallel-opposed, body & 6 & 8.3 \\
\hline incised, vertical, rim & 1 & 1.4 \\
\hline incised, parallel, adjacent to a & 1 & 1.4 \\
\hline \multicolumn{3}{|l|}{ fingernail punctated zonc, body } \\
\hline punctated row, tool, adjacent to & 1 & 1.4 \\
\hline \multicolumn{3}{|l|}{ straight incised line, body } \\
\hline punctated, small circles, body & 1 & 1.4 \\
\hline punctated rows, fingernail. body & 5 & 6.9 \\
\hline punctated row, tool, rim & 2 & 2.8 \\
\hline punctated row, tool, body & 8 & 11.1 \\
\hline Subtotal, utility ware & 54 & 75.0 \\
\hline
\end{tabular}

\section{Fine Ware}

int./ext. red slipped, body

ext. red slipped, body

engraved, cross-hatched column, pendant triangles and excised pendant triangles, bottle, body engraved, curvilinear, body 
Table 5. Decorated Sherds in the Alligator Pond ceramic assemblage, cont.

\begin{tabular}{lll}
\hline Ware and Dccoration & Number & Percentage \\
\hline Fine Ware, cont. & 1 & 1.4 \\
$\begin{array}{l}\text { engraved, parallel and pendant } \\
\text { triangle, bottle, body }\end{array}$ & 2 & 2.8 \\
$\begin{array}{l}\text { engraved, single straight line, body } \\
\text { engraved, triangle, bottle, body }\end{array}$ & 1 & 1.4 \\
engraved, vertical, horizontal, and & 1 & 1.4 \\
opposed lines, bottle, body & 1 & 1.4 \\
excised triangle, bottle, body & 18 & 25.0 \\
$\quad$ Subtotal, fine ware & 72 & 100.0 \\
\hline Totals &
\end{tabular}

The fine ware sherds include both engraved $(n=13)$ and red-slipped $(n=5)$ body sherds (see Table 5). The engraved sherds have straight line elements, parallel lines, as well as hatched and excised triangles, pendant triangles, and cross-hatched columns; sometimes combinations of elements occur on the same vessel, particularly on botlles (see Figure lb-d). The frequency of red-slipped sherds at the Alligator Pond site is notable, given trends in the use and discard of red-slipped vessels in parts of East Texas in Middle Caddo period contexts.

There are 131 chipped stone artifacts in the Alligator Pond site assemblage (Table 6). This includes 17 chipped stone tools, 113 pieces of lithic debris from tool manufacture and maintenance activities, and one core. Almost $18 \%$ of the chipped stone tools are made on non-local cherts, which is a considerable amount, but not when compared to the fact that $55 \%$ of the lithic debris from the site is from the manufacture and/or resharpening of tools made from non-local cherts (i.e., gray, dark brown, light gray, dark grayish-brown, and brownish-gray cherts) and quartz. About $33 \%$ of the lithic debris is on local quartzite. The remainder of the local lithic debris includes petrified wood, ferruginous sandstone, and carth-toned cherts.

Table 6. Chipped Stone Artifacts.

\begin{tabular}{lll}
\hline Category & Number & Percentage \\
\hline $\begin{array}{l}\text { Expanding stent-corner notched } \\
\text { arrow points, quartzite }\end{array}$ & 2 & 1.5 \\
$\begin{array}{l}\text { Contracting stem arrow point } \\
\text { fragment, quartzite }\end{array}$ & 1 & 0.8 \\
Arrow point fragment, quartzitc & 1 & 0.8 \\
Arrow point fragment, gray chert & 1 & 0.8 \\
Arrow point preform. quartzite & 2 & 1.5
\end{tabular}


Table 6. Chipped Stone Artifacts, cont.

\begin{tabular}{|c|c|c|}
\hline Category & Number & Percentage \\
\hline Gary point, quartzitc & 1 & 0.8 \\
\hline Yarbrough point, quartzite & 1 & 0.8 \\
\hline Williams point, brownish-gray chert & 1 & 0.8 \\
\hline Dart point tip, quartzite & 1 & 0.8 \\
\hline Dart point medial fragment, quartzite & 1 & 0.8 \\
\hline Celt preform, petrified wood & 1 & 0.8 \\
\hline Gouge, quartrite & 1 & 0.8 \\
\hline Biface fragment, quartzite & 1 & 0.8 \\
\hline Scraper, gray chert & 1 & 0.8 \\
\hline bilateral flake tool, petrified wood & 1 & 0.8 \\
\hline Subtotal, tools & 17 & 13.0 \\
\hline Lithic debris, total & 113 & 86.2 \\
\hline quartzite & 37 & 28.2 \\
\hline local chert & 8 & 6.1 \\
\hline quartz & 1 & 0.8 \\
\hline petrificd wood & 5 & 3.8 \\
\hline ferruginous sandstone & 1 & 0.8 \\
\hline non-local chert & 61 & 46.6 \\
\hline \multicolumn{3}{|l|}{ Core } \\
\hline single platform, chalcedony & 1 & 0.8 \\
\hline Totals & 131 & 100.0 \\
\hline
\end{tabular}

The chipped stone arrow points from the Alligator Pond include three fragments, two preforms (evidence of on-site arrow point manufacture activities), and two expanding stem, corner-notched arrow points made from the local quartzite. These points may be identified as either Homan or Scallorn points, with both types found in pre-A.D. 1200 Caddo contexts in East Texas sites. The polished petrified wood celt was a woodworking tool also used by the Caddo during their occupation at Alligator Pond.

The one Gary point is a var. Camden specimen. Its occurrence at the site is indicative of some use during the latter part of the Woodland period. The Yarbrough and Williams points at the Alligator Pond site are dart point types that characterizc the Late Archaic in East Texas, and it is estimated that they date between ca. 5000-3000 years old. These points, and probably several of the chipped stone tools listed in Table 6, represent the earliest occupation on the landform. 
In addition to the chipped stone artifacts, there are five ground stone tools in the Alligator Pond site collections. This includes two quartzite and ferruginous sandstone manos, with ground smoothed areas on either one or both surfaces. The manos range from $103-114 \mathrm{~mm}$ in length, $82-88 \mathrm{~mm}$ in width, and $35-45$ $\mathrm{mm}$ in thickness. There is a ferruginous sandstone metate with a $15 \mathrm{~mm}$ deep concave depression on one side in its center, this being the active grinding and pounding area. The metate is $175 \mathrm{~mm}$ in length, 170 $\mathrm{mm}$ in width, and $50 \mathrm{~mm}$ thick. There is also a coarse-grained ferruginous sandstone pitled stone with a $20 \mathrm{~mm}$ circular depression on one side. This tool is $91 \times 62 \mathrm{~mm}$ in length and width, and $42 \mathrm{~mm}$ thick. The final ground stone tool is the poll end of a Caddo tradition quartzitic sandstone celt fragment; this material originates in the Ouachita Mountains of southeastern Oklahoma, but is also present in gravels in the middle reaches of the Red River valley, well north of Saline Creck in East Texas.

Six pieces of fire-cracked rock (FCR) from the hot rock cooking of plant foods in ovens and pits are in the Alligator Pond site collections. Firc of the FCR are quartzite, and the other is hematite, both local stone raw materials.

\section{Thacker Farm House (41SM444)}

The Thacker Farm House site is located on a gravelly upland landform about $1.1 \mathrm{~km}$ east of Saline Creek. Soils are a Redsprings very gravelly sandy loam (2-5\% slopes). The site area, estimated at $2500 \mathrm{~m}^{2}$ ( 0.62 acres), is in a clcared orchard, but orchard plantings and weeds limit the surface visibility to $10 \%$.

A total of 140 Caddo ceramic vessel sherds are in the collections from the Thacker Farm House, including 104 plain sherds (one rim, 98 body sherds, and five base sherds) and 36 decorated sherds. The plain to decorated sherd ratio is a moderate 2.89 .

The sherds are from grog-tempcred vessels, with some vessels also having bone (3.6\%) and crushed hematite temper inclusions (Table 7). The detailed analysis of a sample of thc sherds suggests that most of the sherds are from unsmoothed vessels that were fired in a reducing environment, while $20 \%$ are from ressels that were incompletely oxidized during firing. Vessel walls of these vessels were relatively thick (mean thickness of $8.3 \pm 0.9 \mathrm{~mm}$ ), likely because vessels at the site wcre large in size, and some may have served as durable storage vessels with extra-thick body walls.

Table 7. Detailed analysis of Caddo sherds from the Thacker Farm House site.

\begin{tabular}{llllll}
\hline Sherd type & Temper & FC & ST & $\begin{array}{l}\text { Th } \\
(\mathrm{mm})\end{array}$ & Comments \\
\hline body & grog & C & - & 9.6 & $\begin{array}{l}\text { parallel incised and straight } \\
\text { appliqued ridge } \\
\text { parallel brushed }\end{array}$ \\
body & grog & F & - & 7.3 & parallel incised lines \\
body & grog & B & - & 7.6 & plain \\
body & grog & G & - & 8.3 & plain \\
body & grog & C & - & 7.6 & plain \\
body & grog & F & - & 10.8 & plain \\
body & grog & F & & 7.7 & plain \\
body & grog-bone & G & I SM & 9.0 & parallel incised lines \\
body & grog-hem. & F & - & 7.4 & plain \\
body & grog-hem. & F & - & 7.7 &
\end{tabular}

hem =hematite $\mathrm{FC}=$ hring conditions; $A=$ =hred and cooled in an oxidizing environment: $(-$ E. incompletely oxidized duning firing: $\mathrm{B}=$ fired and cooled in a reducing environment; $\mathrm{F}-\mathrm{G}=$ fired in a reducing environment and cooled in the open air: $\mathrm{ST}$ surface treatment: $\mathrm{I}=$ interior; $\mathrm{E}=$ exterior; $\mathrm{SM}=$ smoothed; Th=thickness 
Table 8. Selected lithic comparisons between the Saline Creek sites.

\begin{tabular}{|c|c|c|c|c|}
\hline Sites & $\begin{array}{l}\% \text { Non-local } \\
\text { chert artifacts }\end{array}$ & $\begin{array}{l}\text { Arrow Points } \\
\text { and Types }\end{array}$ & $\begin{array}{l}\text { Dart Points } \\
\text { and Types }\end{array}$ & $\begin{array}{l}\text { Projectile Point to } \\
\text { Ground stone Ratio }\end{array}$ \\
\hline SM442 & 47.0 & $\begin{array}{l}\text { 7. Scallorn \& } \\
\text { Homan; preform; } \\
\text { fragments }\end{array}$ & $\begin{array}{l}\text { 5, Gary (1), } \\
\text { Williams (1) } \\
\text { Yarbrough (1) }\end{array}$ & $12: 5$ \\
\hline SM444 & 20.0 & - & Yarbrough (1) & $1: 0$ \\
\hline SM440 & 24.8 & 1, preform & $\begin{array}{l}8 . \text { Gary (5), } \\
\text { Yarbrough (2) }\end{array}$ & $9: 4$ \\
\hline SM441 & 25.7 & $\begin{array}{l}4, \text { Alba (3), } \\
\text { Perdiz (1) }\end{array}$ & Gary (1) & $5: 1$ \\
\hline
\end{tabular}

The 36 decorated sherds are primarily from utility ware vessels $(n=33,91.6 \%$ of the decorated sherds), with only three engraved fine wares ( $8.3 \%$ of the decorated sherds). The utility ware sherds include brushed $(n=18)$, incised $(n=12)$, brushed-punctated $(n=1)$, incised-appliqued $(n=1)$, and incisedpunctated $(n=1)$.

The brushed body sherds have parallel brushing marks, likely from jars with vertical brushing, but the orientation of the brushing cannot be determined with confidence. All 12 incised body sherds have straight to parallel incised lines, but again the orientation of the incised decorations is not known. One body sherd has parallel brushing, with tool punctates pushed through the brushing; this is a common vessel decoration in both Middle and Late Caddo times. Another body sherd has parallel incised lines adjacent to a straight appliqued ridge; the latter was likely used to divide a vessel body into quadrants filled with different decorations; in this case, the quadrants probably were filled with vertical incised lines. Finally one incised-punctated rim sherd has opposed diagonal incised lines that create triangular zones: these zones arc tilled with tool punctates.

One line ware rim sherd from a carinated bowl has two horizontal engraved lines on the rim panel. A body sherd has closely-spaced parallel engraved lines. The last engraved body/lower rim sherd (see Figure 1e) has a hatched bracket or divider, likely from a Poynor Engraved, var. Hood vessel (see Pertula 2011:Figure 6-64e).

The lithic assemblage from the site is sparse, including only one dart point and four pieces of lithic debris. The dart point is a Late Archaic Yarbrough point made from a locally available quartzite. Both local (quartzite and brown chert) and non-local (gray chert) lithic raw materials were knapped at the site. although this was done sparingly.

\section{SUMMARY AND CONCLUSIONS}

Overall, the character of the lithic and ceramic artifacts from the four Saline Creek sites seems to indicate that this part of the valley was first settled by aboriginal peoples about 5000 years ago, at the beginning of the Late Archaic period. This period is marked by the recovery of Williams and Yarbrough dart parts at three of the sites, as well as a range of chipped and ground stone tools (Table 8). Likewise, during the latter part of the Woodland period, three of the four Saline Creek sites were occupied - as evidenced by the documentation of Gary, var. Camden dart points at the three sites-by Woodland peoples ancestral to the Caddo peoples that lived in East Texas after ca. A.D. 850. The Alligator Pond site 
(41SM442) also had two sherds from Goose Creek Plain, var. unspecified sandy paste Woodland period vessels. The occurrence of ceramic sherds at the site, often taken as one indicator of the development of a more sedentary lifeway, suggests that the occupation during this timc at the Alligator Pond site may have been more than a hunting and food processing camp, but a camp where the Woodland peoples may have stayed for a longer period of time during a seasonal occupation. Projectile point to ground stone tool ratios from the four sites suggest that hunting was a major pursuit at each of the sites, although plant foods were processed at them as well using ground stone manos, metales, and pitted stones.

A notable characteristic of the lithic assemblages from the Saline Creek sites is the use of non-local chert artifacts in the chipped stone tools, the polished celts, and the chipped stone lithic debris (see Table 8). At the Alligator Pond site, the percentage of non-local chert artifacts is $47 \%$, while the other three have comparable, but lower, percentages of non-local cherts in their assemblages (20.0-25.7\%). While it is uncertain just how many of the chipped stone artifacts from the sites can be associated with the prehistoric Caddo occupations, the fact that the Alligator Pond site is apparently the earliest site among the four Saline Creek sites, it does open up the tantalizing possibility that the earlier Caddo peoples that settled in the basin had a better and broader access to non-local sources of non-local cherts (either by direct procurement or through trade and exchange). The later Caddo peoples that settled in the basin did not have the same ready access to non-local chert raw materials, and thus they had to depend on local raw materials such as quartzite, petrified wood, and ferruginous sandstone.

The major settlement of the Saline Creek valley was by the ancestors of modern Caddo people. During the Caddo occupation of the Saline Creck sites, including a relatively intensive and early occupation at Alligator Pond, arrow point preforms, arrow point lragments, and several identifiable arrow point styles suggest the sites were first occupied before ca. A.D. 1000 and continued to be occupied episodically and on a generational basis until sometime after ca. A.D. 1300 (see Table 8). Given what we know about the ccramics from these four sites, the Alligator Pond was occupied the earliest during the Caddo era, while the other three - Sarah's Deer Stand (41SM440), Handicap Deer Stand (41SM441), and Thacker Farm House (41SM444) - may have been occupied at least one or two ccnturies later, but betwecn them, more or less contemporaneously. These occupations are modest in size, from 2500-6000 $\mathrm{m}^{2}$, and probably represent permanent year-round occupations by one or a few Caddo families, probably farmsteads or a small hamlet. All three sites may be part of one larger Caddo community in this part of the upper Sabine River basin.

Through several means of ceramic comparisons (Table 9), the four Saline Creek sites can be readily sorted into two groups: Group I, the Alligator Pond site, with a very high plain to decorated sherd ratio (P/DR), little brushed pottery in the assemblage, considerable numbers of wet paste utility ware ceramic sherds, and a relatively low use of bone as a temper; and Group II, the other three sites that may be part of the same community of peoples. The Group II sites have moderate P/DR values, considerable percentages of brushed decorated sherds, lowcr frequencies $(40-50 \%)$ of wet paste utility wares, and the use of bone temper was moderate at two of the three Group II sites.

P/DR values from numerous Caddo sites in East Texas appear to hold considerable promise as an independent means of establishing the age of Caddo ceramic-bearing components (provided samples of plain and decorated sherds are larger than about 200-300 sherds per site, which three of the four sites on Saline Creek do not meet. Nevertheless, the P/DR comparisons for these assemblages still prove useful). When $\mathrm{P} / \mathrm{DR}$ ratios from a number of different ceramic assemblages from the various ceramic traditions/regions in East Texas are linked with absolute ages as established by radiocarbon dating from those assemblages, it is expected that further refinements in how P/DR ratios change through time in East Texas Caddo sites will be established. At the moment, looking at Early Caddo to Historic Caddo ceramic assemblages in the region through time, the trend is that ceramic assemblages have lower proportions of undecorated sherds through time and thus a lower P/DR ratio (Perttula 2008:9,315-317). Analyzed pre-A.D. 1200 sites in East Texas have plain/decorated sherd ratios that appear to range from 2.97 to greater than 4.80; the Alligator Pond site P/DR of 5.99 fits this pre-A.D. 1200 P/DR rangc (see Tablc 9). Middle Caddo sites (ca. A.D. 1200-1450) 
Table 9. Selected ceramic comparisons between the Saline Creek sites.

\begin{tabular}{llllll}
\hline Sites & $\begin{array}{l}\text { Plain/Decorated } \\
\text { Sherd Ratio }\end{array}$ & \% Brushed* & $\begin{array}{l}\text { Wet } \\
\text { Paste } \%\end{array}$ & $\begin{array}{l}\text { \% Bone- } \\
\text { Tempered }\end{array}$ & N \\
\hline Group I & & & & & \\
41SM442 & 5.99 & 9.7 & 68.1 & 7.0 & $503+$ \\
Group II & & & & & \\
41SM444 & 2.89 & 50.0 & 41.6 & 3.6 & 140 \\
41SM440 & 2.69 & 47.6 & 50.0 & 12.9 & 155 \\
41SM441 & 2.13 & 46.7 & 40.0 & 17.0 & 47 \\
\hline
\end{tabular}

*percent brushed among all decorated sherds from the site; ** percent wet paste (i.e., incised, punctated, appliqued, incised-punctated, etc.) among all decorated sherds from the site

tdoes not include two Woodland period sandy paste sherds

have ratios that range between 1.30-2.65; the three other Saline Creek sites generally fall in the Middle Caddo period based on their P/DR (see Table 9). In known Late Caddo sites in the Neches, Angelina, and Sabine river basins, by contrast, the P/DR ranges from only 1.30-0.47. Finally, post-A.D. 1680 Caddo occupations in the Neches-Angelina river basin have P/DR ratios that range from 0.20-0.30.

Further chronological confirmation of the ages of the four Caddo components is reflected in the percentages of brushed pottery in each assemblage (see Table 9). At the earlier Alligator Pond site, only $9.7 \%$ of the decorated sherds are brushed, compared to between $46.7-50.0 \%$ in the three other Saline Creek sites. It has been shown repeatedly in Caddo ceranic studies in much of East Texas (although not including the Red River valley, where brushed pottery is almost non-existent) that the proportion of brushed sherds in decorated sherd assemblages steadily increases through time, beginning around ca. A.D. 1200. By the early 15th century A.D., however, Caddo potters in the upper Neches River basin and parts of the upper Sabine River basin began to manufacture considerable numbers of jars with brushed vessel bodies and rims (Perttula 2011). Given the relatively high proportion of brushed sherds in three of the Saline Creek sites, and their ceramic assemblage P/DR values, it seems likely that they were occupied during the latter part of the 14th century through the mid-15th century A.D., and were probably abandoned after that time. The low percentage of brushed sherds, in concert with the high P/DR values, at the Alligator Pond site is primarily consistent with a pre-A.D. 1200 occupation, or at least an occupation that ended by that time.

How do the three Group II Caddo ceramic sites on Saline Creek compare to ceramic assemblages at other generally contemporaneous Caddo sites in the upper Sabine River such as Leaning Rock (Walters 2008), the Wolf site (Walters 2003), Bryan Hardy (Walters and Haskins 2000), Redwine (Walters and Haskins 1998), and Carlisle (Perttula et al. 1993). Using the same attribute comparisons from Table 9 , Table 10 provides relevant attribute-level ceramic data from these five excavaled sites on their P/DR; the percentage of brushed sherds among all the decoratcd sherds; the percentage of wet paste decorated sherds among all the decorated sherds; and the percentage use of bone temper. Each of these five sites also have either radiocarbon or OCR dates to establish the absolute age of their Middle Caddo occupations, and these range frum as early as A.D. 1276 to as late as A.D. 1449, almost the full gamut of the Middle Caddo period in the upper Sabine River basin. 
Table 10. Upper Sabine River Middle Caddo Sites and Ceramic Assemblages.

\begin{tabular}{|c|c|c|c|c|c|}
\hline Site & $\mathrm{P} / \mathrm{DR}$ & $\%$ Brushed & $\%$ Wet Paste & $\begin{array}{l}\text { \% Bone } \\
\text { Temper }\end{array}$ & $\begin{array}{l}\text { C14 and OCR } \\
\text { Dates }\end{array}$ \\
\hline $\begin{array}{l}\text { Leaning Rock, } \\
4 \text { ISM } 325\end{array}$ & 3.59 & 20.8 & 66.3 & 21.7 & $\begin{array}{l}\text { mean } 2 \text { sigma } \\
\text { calibrated age: } \\
\text { AD } 1297-1389\end{array}$ \\
\hline $\begin{array}{l}\text { Wolf, } \\
41 \text { SM195 }\end{array}$ & 3.37 & $0 \%$ & 70.5 & 49.2 & $\begin{array}{l}\text { C14, } 2 \text { sigma: } \\
\text { AD 1315-1440; } \\
\text { OCR:AD 1317- } \\
1413\end{array}$ \\
\hline $\begin{array}{l}\text { Bryan Hardy, } \\
41 \text { SM55 }\end{array}$ & 1.30 & 37.7 & 70.7 & $\begin{array}{l}\text { grog-bone } \\
\text { temper, but } \\
\% \text { not } \\
\text { specified }\end{array}$ & $\begin{array}{l}2 \text { sigma C14, } \\
\mathrm{AD} 1277-1401\end{array}$ \\
\hline $\begin{array}{l}\text { Redwine, } \\
41 \text { SM193 }\end{array}$ & 3.36 & 35.5 & 48.6 & 44.5 & $\begin{array}{l}2 \text { sigma C14, } \\
\text { AD 1304-1434 }\end{array}$ \\
\hline $\begin{array}{l}\text { Carlisle, } \\
41 \text { WD46 }\end{array}$ & 2.72 & 51.3 & 35.8 & 5.0 & $\begin{array}{l}2 \text { sigma C } 14, \\
\text { AD) } 1276-1449\end{array}$ \\
\hline
\end{tabular}

In a general sense, the most interesting aspect of these upper Sabine River basin ceramic assemblages is how different they are one from another, as if they represent assemblages from different local or community-wide ceramic traditions. P/DR values range from 1.30-3.59, even though the sites are contemporaneous, indicating that the proportions of decorated and plain vessels in each assemblage are rather divergent; this is especially the case for the Bryan Hardy site (a P/DR of 1.30) in comparison to the other four sites (P/DR values of 2.72-3.59). The proportion of brushed pottery ranges from $0.0-51.3 \%$, and the proportion of wet paste decoratcd sherds range considerably from $35.8-70.7 \%$. With the exception of Bryan Hardy, which has many brushed-punctated sherds (see Walters and Haskins 2000), the sites with the highest proportions of brushed pottery (Carlisle and Redwine) also have the lowest proportions of wet paste decorated sherds (see Table 10). Finally, while bone temper was used in the manufacture of ceramic vessels in all five Middle Caddo sites in the upper Sabine River basin, its use ranged from a low of 5\% at the Carlisle site to $49.2 \%$ at the Wolf site.

Based simply on the comparison of these ceramic assemblage attributes, the Group II Middle Caddo sites on Saline Creek appear to be most closely affiliated with the (addo peoples that lived at the Carlisle site and other nearby sites (4IWD245 and 4IWD507, sec Perttula et al. 1993:57-58), at and near the confluence of Lake Fork Creek and the Sabine River, about $16 \mathrm{~km}$ north and east of the Saline Creek sites. The Middle Caddo sites in northern Smith County appcar to represent occupations by at least three different communities of people. This close ceramic similarity between the Saline Creek sites and sites in the Sabine/Lake Fork confluence area thus implies that the Saline Creek sites also date from the latter part of the 13 th century to the mid-part of the 15 th century A.D.

\section{ACKNOWLEDGEMENTS}

Perttula would like to thank Mark Thacker, the landowner, for the opportunity to document the collections from his property in Smith County, Texas. The junior author, Mark Walters, facilitated the study, as only a great Texas Archeological Steward Network steward can. 


\section{REFERENCES CITED}

Aten, L. E. and C. N. Bollich

2011 Early Ceramic Sites of the Sabine Lake Area, Coastal Texas and Louisiana. Studies in Archeology 43. Texas Archeological Research Laboratory, The University of Texas at Austin.

Diggs Jr., G. M., B. L. Lipscomb, M. D. Reed and R. J. O'Kennon

2006 Illustrated Flora of East Texas, Volume One: Introduction. Pteridophytes, Gymnosperms, and Monocotyledons. Sida, Botanical Miscellany, No. 26. Botanical Research Institute of Texas, Fort Worth.

Hatherly, D. T.

1993 Soil Survey of Smith County, Texas. United States Department of Agriculture, Soil Conservation Service, in cooperation with the Texas Agricultural Experiment Station and the Texas State Soil and Water Conservation Board, Washington, D.C.

Perttula, T.K.

2011 The Ceramic Artifacts from the Lang Pasture Site (41AN38) and the Place of the Site within an Upper Neches River Basin Caddo Ceramic Tradition. In Archeological Investigations at the Lang Pasture Site (4/AN38) in the Upper Neches River Basin of East Texas, assembled and edited by T. K. Perttula, D. B. Kelley, and R. A. Ricklis, pp. 145-320. Archeological Studies Program Report No. 129, Texas Department of Transportation, Environmental Affairs Division, Austin.

Perttula, T. K. (editor)

2008 Lake Naconiche Archeology, Nacogdoches County, Texas: Results of the Data Recovery Excavations at Five Prehistoric Archeological Sites. 2 Vols. Report of Investigations No. 60. Archeological \& Environmental Consultants, LLC, Austin.

Perttula, T. K., B. D. Skiles, and B. C. Yates

1993 The Carlisle Site (41 WD46), a Middle Caddoan Occupation on the Sabine River. Wood County, Texas. Notes on Northeast Texas Archaeology 1:34-62.

Samford, P. M.

2000 Response to a Market: Dating English Underglaze Transfer-Printed Wares. In Approaches to Material Culture Research for Historical Archaeologists, compiled by D. R. Brauner, pp. 56-85. $2^{\text {nd }}$ Edition. The Society for Historical Archaeology, California, Pennsylvania.

Schambach, F. F.

1982 An Outline of Fourche Maline Culture in Southwest Arkansas. In Arkansas Archeology in Review, edited by N. L. Trubowitz and M. D. Jeter, pp. 132-197. Research Series No. I5. Arkansas Archeological Survey, Fayetteville.

Story, D. A.

2000 Introduction. In The George C. Davis Site, Cherokee County, Texas, by H. P. Newell and A. D. Krieger, pp. 1-31. 2nd Edition. Society for American Archaeology, Washington, D.C.

Story, D. A. (editor)

1995 The Deshazo Site, Nacogdoches County, Texas, Vol. 2: Artifacts of Native Manufacture. Studies in Archeology 21. Texas Archeological Research Laboratory, The University of Texas at Austin.

Suhm, D. A., and E. B. Jelks (editors)

1962 Handbook of Texas Archeology: Type Descriptions. Special Publication No. 1, Texas Archeological Society, and Bulletin No. 4, Texas Memorial Museum, Austin. Reprinted in 2009, Gustav`s Library, Davenport, Iowa. 
Turner, E. S. and T. R. Hester

1999 A Field Guide to Stone Artifacts of Texas Indians. Gulf Publishing, an imprint of Rowman \& Littlefield Publishers, Inc., Lanham, Maryland.

Walters, $M$.

2003 The Wolf Site (41SM195), Smith County, Texas. Journal of Northeast Texas Archaeology 18:121.

Walters, M., with contributions from L. G. Cecil, L. S. Cummings, J. P. Dering, J. R. Ferguson, M. D. Glascock, T. K. Perttula, L. Schnicbs, H. J. Shafer, J. Todd, and C. P. Walker

2008 Life on Jackson Creek, Smith County, Texas: Archeological Investigations of a 14th Century Caddo Domicile at the Leaning Rock Site (4ISM325). Caddo Archeology Journal 17:1-114.

Walters, M. and P. Haskins

1998 Archaeological Investigations at the Redwine Site (41SM193), Smith County, Texas. Journal of Northeast Texas Archaeology 11:1-38.

2000 The Bryan Hardy Sitc (41SM55), Smith County, Texas. Journal of Northeast Texas Archaeology 12:1-26. 